\title{
Intimate Partner Violence in a U.S. College Sample: Do Auditory Status and Gender Predict Victimization?
}

\author{
Mark Beaulieu', LaVerne McQuiller Williams ${ }^{2 *}$, Judy L. Porter ${ }^{2}$ \\ ${ }^{1}$ State University of New York College, Plattsburgh, USA \\ ${ }^{2}$ Rochester Institute of Technology, Rochester, USA \\ Email: ${ }^{*} 11 m g c j @ r i t . e d u$
}

How to cite this paper: Beaulieu, M., McQuiller Williams, L., \& Porter J. L. (2017). Intimate Partner Violence in a U.S. College Sample: Do Auditory Status and Gender Predict Victimization? Psychology, 8, 387411.

https://doi.org/10.4236/psych.2017.83024

Received: December 17, 2016

Accepted: February 17, 2017

Published: February 20, 2017

Copyright $\odot 2017$ by authors and Scientific Research Publishing Inc. This work is licensed under the Creative Commons Attribution International License (CC BY 4.0).

http://creativecommons.org/licenses/by/4.0/

\begin{abstract}
Our research examines the effect of auditory status and gender on self-reported psychological and physical abuse of college students from a northeastern university in the United States. A total of 816 college students were surveyed. Forty classes were randomly selected and surveys were administered to students in those classes. Predictions from disability theory, feminist theory, and feminist disability theory were tested using binary logistic regression analysis. Gender specific binary logistic regressions were run to examine the possibility that predictors of abuse differ by gender. Disability theory predicted that Deaf and hard of hearing students were at a higher risk for reporting victimization. The results from the analyses support disability theory and show that Deaf and hard of hearing students were more likely to report victimization. Feminist theory predicted that women would be more likely to be abused than men. Feminist theory received mixed support. Women regardless of auditory status were more likely to report psychological abuse, but were not more likely to report physical abuse. Feminist disability theory hypothesized that the risk of abuse would be higher for Deaf and hard of hearing women than for either hearing women and men, and Deaf and hard of hearing men. Feminist disability theory was tested by including an interaction effect (auditory status by gender). Feminist disability theory received no support. The interaction effect between auditory status and gender was negative, indicating that Deaf and hard of hearing women college students were less likely to report victimization than one would expect when the interaction effect is not included in the model.
\end{abstract}

\section{Keywords}

Auditory Status, Victimization, Feminist Disability Theory 


\section{Introduction}

Over the past three decades, increased attention has been paid to intimate partner violence (IPV) among persons with disabilities. For the purposes of this study, intimate partner violence refers to violence between individuals in dating and cohabiting relationships and encompasses physical, psychological, and sexual abuse (World Health Organization, 2012). Studies using community samples suggest that individuals with mental and physical disabilities are at an increased risk for experiencing IPV than people without disabilities (Brownlie, Jabbar, Beitchman, Vida, \& Atkinson, 2007; Brownridge, 2006; Knutson, Johnson, \& Sullivan, 2004; Nannini, 2006; Powers et al., 2009; Sebald, 2008; Spencer et al., 2005; Sullivan \& Knutson, 2000; Turner, Vanderminden, Finkelhor, Hamby, \& Shattuck, 2011). Recently, a handful of studies have focused on IPV among college students with disabilities, particularly students that are Deaf ${ }^{1}$ or hard of hearing (Anderson, 2010; Anderson \& Leigh, 2011; Mason, 2010; Porter \& McQuiller Williams, 2011a, b). These empirical studies contribute to our understanding of the prevalence of IPV among Deaf and hard of hearing college students; however, a theoretical framework to conceptualize Deaf and hard of hearing college students' experiences with IPV is lacking from these studies.

It is important to study the experiences of those who are Deaf and hard of hearing as previous studies based on U.S. community samples have indicated that Deaf and hard of hearing individuals are more likely to be victimized over their lifetime than hearing individuals (Brownridge, 2009; Johnston-McCabe, Levi-Minzi, Van Hassely, \& Vanderbeek, 2011). Moreover, recent studies using college samples in the U.S. indicate that prevalence rates of experiencing intimate partner violence were more than doubled for Deaf and hard of hearing individuals when compared to hearing populations (Anderson, 2010; Anderson \& Leigh, 2011; Porter \& McQuiller Williams, 2011a; Porter \& McQuiller Williams, 2011b). For example, in a recent study conducted by Anderson and Leigh (2010), a significantly higher proportion of Deaf women undergraduates at a college in Washington, D.C. reported IPV victimization (i.e., physical assault and psychological aggression) than hearing students in the previous year. Similarly, using randomized samples of over 1000 college men and women, including over 200 Deaf and hearing students at a large U.S. northeastern university, it was found that Deaf and hard of hearing college students were twice as likely to report psychological abuse and nearly two and a half times more likely to experience physical abuse at the hands of a partner than hearing students in the prior year (Porter \& McQuiller Williams, 2011a; Porter \& McQuiller Williams, 2011b). Studies of IPV among Deaf or hard of hearing college students at Gallaudet University in Washington, D.C. found psychological abuse to be more prevalent $(30 \%)$ than physical abuse $(11 \%)$ in their current relationships among

${ }^{1}$ In the United States, Deaf people do not see themselves as having a disability, but rather have a culture and way of communication that is denied by the dominate hearing culture (Sadusky \& Obinna, 2002). The use of the capital " $D$ " is to acknowledge the unique cultural identity of Deaf individuals. This includes a strong affiliation to the Deaf community and a shared language (American Sign Language) (Anderson, Leigh, \& Samar, 2011). 
the Deaf or hard of hearing men and women respondents (Mason, 2010). A study of IPV of Deaf and hard of hearing undergraduate women during the last 12 months, at the same university, by Anderson and Leigh (2011) found psychological and physical abuse to be much more prevalent (over $90 \%$ and 50\%). The discrepant findings between these studies may be explained by the differing measures and respondents surveyed for partner violence. For example, Mason (2010) used the measure of being assaulted "at least sometimes", while the other studies used one incident to qualify as intimate partner violence. In addition, while Anderson and Leigh's (2011) study only focused on women, Porter and McQuiller's (2011a, 2011b) and Mason's (2010) studies included both men and women. It may be that the reported prevalence rates across studies may change when separated by gender.

Using a survey-instrument with a sample of college students in the northeastern United States, the purpose of the current study is to test three theoretical frameworks with regard to psychological and physical abuse: disability theory, feminist theory, and feminist disability theory. Psychological abuse and physical abuse are harmful and psychological abuse can often precede physical abuse victimization (Aosved \& Long, 2005), so it is important to study each type of abuse separately. Based on arguments set forth by disability theory, we will test if male and female Deaf and hard of hearing college students are more likely to be victims of psychological and physical abuse than male and female hearing students. This is an important contribution to the literature on IPV given that few studies have examined IPV against men with disabilities, and no prior studies have tested theories related to IPV among men with disabilities. Based on arguments set forth by feminist theory, we will test if women are more likely to be victims of psychological and physical abuse than men. Finally, based on arguments put forth by feminist disability theory, we will test if Deaf and hard of hearing women are more likely to report psychological abuse and physical abuse than would be predicted based on their auditory status and gender (Mays, 2006; Smith \& Anderson, 2004). To our knowledge no other study has tested feminist disability theory exclusively with Deaf and hard of hearing college students and their experiences of physical or psychological abuse.

\section{Theoretical Framework}

\subsection{Disability Theory}

Disability theory provides an explanation about why persons with disabilities are more likely to suffer abuse than persons without disabilities. Disability theory points to the isolation, lack of power, and unequal access to resources that persons with disabilities experience (Smith, 2007). Disability theory moves beyond traditional theories of domestic abuse and violence that do not adequately account for the experiences of persons with disabilities and have not considered the effects of marginalization and oppression of those who have disabilities (Mays, 2006; Smith \& Anderson, 2004). Many studies have found that women with disabilities are at a higher risk for IPV than women without disabilities 
(Brownridge, 2006; Brownridge, Ristock, \& Hiebert-Murphy, 2008; Chenoweth, 1997; Collins et al., 1999; Hague, Thiara, \& Magowan, 2007; Luthra \& Gidycz, 2006; McFarlane et al., 2001; Nosek et al., 1995; Smith, 2007; Sobsey \& Doe, 1991; Young, Nosek, Howland, Chanpong, \& Rintala, 1997).

Several studies found that partners of women with disabilities were more likely to be perpetrators of IPV than partners of women without disabilities (Collins et al., 1999; Martin et al., 2006; McFarlane et al., 2001; Young et al., 1997). Women with disabilities face a complex set of circumstances that is specific to their disability and many say that the abuse they experience is broader than is usually defined by IPV studies. Abuse may include not only typical IPV experiences but also abuse specific to their circumstances and the abuse is likely to cover a longer period of time than women without disabilities experience (Young et al., 1997). Such abuse may include being humiliated and ridiculed, having medication or devices necessary to their functioning withheld, needed services or help withheld, isolation via withheld communication devices, and financial abuse (Depoy, Gilson, \& Cramer, 2003; Hague et al., 2007; Hague, Thiara, Magowan, \& Mullender, 2008).

The National Crime Victimization Survey (NCVS; Harrell, 2011) "defines disability as a sensory, physical, mental, or emotional condition lasting 6 months or longer and causing difficulty in activities of daily living" (p. 1). The NCVS categorizes limitations into six categories: hearing, vision, cognitive, ambulatory, and limitations in either self-care or independent living. The limitation category under hearing includes "deafness or serious difficulty hearing" (Harrell, 2011). The Harrell (2011) examines violent crime rates against persons with disabilities both with type of disability aggregated and with the six categories disaggregated although some victims have more than one disability. The data is further examined by gender. Overall, women with a hearing disability experience more violent victimization than men with a hearing disability.

While disability theory is important in the study of all types of disabilities, it is equally important to study each type of disability separately as the circumstances for each type of disability and their associated problems vary widely. Victims of IPV who are Deaf or hard of hearing, for example, face "disability specific forms" of abuse. For example, psychological abuse may include the perpetrator insulting the victim by calling the victim "hearing" or making fun of his/her sign language skills, signing very close to the victim's face (Anderson, 2014), or tying the victim's hands to prevent the victim from signing (Packota, 2000). Recent studies have demonstrated that IPV among the Deaf and hard of hearing community is an important issue (Anderson, 2010; Anderson \& Leigh, 2011; Anderson, Leigh, \& Samar, 2011; Porter \& McQuiller Williams, 2011a, 2011b) that warrants further study. Disability theory would predict that persons with disabilities would be at a higher risk of physical or psychological abuse than those who did not have a disability.

Hypothesis 1 (Disability hypothesis): Deaf and hard of hearing college 
students will be more likely to report experiencing physical and psychological abuse by intimate partners than hearing college students.

\subsection{Feminist Theory}

Feminist theory suggests that the oppression of women by men in society and in interpersonal relationships forms the basis of male perpetration and women's victimization (Anderson, 1997; Brownridge, 2006; Brownmiller, 1975; Burt, 1980). Subordination and control of women is achieved via the use of either the actual acts of abuse and violence or the fear of such abuse and violence that is perpetrated by intimate partners and also by strangers or acquaintances (Howe, 2000). Furthermore, feminist theory posits that interpersonal violence is not a private matter but a public one that should be addressed in the public arena (Dobash \& Dobash, 1979; Walker, 1979). According to the U.S. Department of Justice, women aged 16 - 24 are at the greatest risk of non-fatal violence from an intimate partner (U.S. Department of Justice, 1998).

Feminist theory concerning IPV posits that gender and unequal power, including inequality in education and income (Atkinson, Greenstein, \& Lang, 2005) affects heterosexual relationships (Franklin \& Menaker, 2014; Schwartz \& DeKeseredy, 1997). Many studies have found a relationship between male perpetrated IPV when there are higher levels of belief in patriarchy and traditional gender roles as well as when there are educational and employment inconsistencies (for example when the woman has a greater salary or has attained a higher level of education than the man in the relationship) (Anderson, 1997; Atkinson, Greenstein, \& Lang, 2005; Basile, Hall, \& Walters, 2013; DeKeseredy \& Schwartz, 1998; Gelles, 1974; Macmillan \& Gartner, 1999; Yllo, 1983, 1984; Yodanis, 2004). For example, Atkinson et al. (2005) used the National Survey of Families and Households survey of 4296 households. Their analysis revealed that physical non-sexual abuse increased for married women who earned more than their husbands and among those who held a belief in traditional gender roles as compared to others who held more egalitarian views. Franklin and Menaker's (2014) study of 300 women sought to examine the effects of patriarchal family ideology and non- traditional status in employment or education on IPV. The study combined psychological and physical abuse into an aggregated variable of "any victimization" (p. 8). Findings indicated that when both partners were employed IPV increased with men perpetrating against women. Patriarchal ideology and education inconsistency did not achieve significance in the study but violence in the family of origin did-for those who had witnessed family violence as a child, male perpetrated IPV increased. Basile, Hall and Walters (2013) tested a feminist-informed theory of IPV and resource theory using data from 340 men who were arrested for physical assault of their partner. Both theoretical approaches were partially supported; however, the feminist-informed theoretical model was better supported. The feminist-informed perspective accounted for $33 \%$ of the variance in psychological abuse and $29 \%$ of the variance in physical abuse. 
In a patriarchal society men are socialized to use violence and aggression; women are socialized to be non-violent and passive (Johnson, 2005; Lorber, 2001). Studies have found that status or power inequalities, patriarchal and traditional beliefs about gender roles play a role in the perpetration of IPV (Anderson, 1997; Atkinson et al., 2005; Claes \& Rosenthal, 1990; DeKeseredy \& Schwartz, 1998; Gelles, 1974; Macmillan \& Gartner, 1999; McCloskey, 1996; Yodanis, 2004). Two macro-level studies by Yllo (1983, 1984) found support for feminist theory. Gender role ideology, women's educational and income status, and the prevalence of male dominated families impact the risk of IPV. States wherein more traditional gender roles predominated also had the highest levels of IPV. Interestingly, women residing in states wherein women represented a higher proportion of high status in education, politics, and professions had a greater risk of IPV only among those families where the husband held a traditional dominant role. Feminist theory would posit that the heightened risk women experience for becoming a victim of physical or psychological abuse is related to gender, to women's positions in society, and their status in their relationships. Additionally, when women are less accepting of traditional feminine roles and their partners endorse patriarchal beliefs, there is a greater likelihood of IPV perpetration against the woman (DeKeseredy \& Schwartz, 1998). Thus, feminist theory would predict that women would be at a greater risk for psychological and physical abuse than men.

In college samples, both men and women have been found to experience abusive behaviors while in college (Harned, 2001; Forke et al., 2008; Perry \& Fromuth, 2005). The concept of IPV perpetrated by women is contrary to feminist theory, in that it runs counter to arguments of patriarchal power and control. However, feminists and others have suggested that women perpetrated IPV is not contrary to feminist theory in that it is the result of self-defense and fear (Dobash et al., 1992; Dutton \& Nicholls, 2005; Saunders, 1998), and thus, the context of IPV needs to be examined. For example, Cercone et al.'s (2005) study of 414 college students found that women and men were equally likely to commit minor acts of violence (e.g., slapping. kicking, and biting) against their partner. While the rates of perpetrating physical violence were similar for men and women, the authors found differences in the context of violence (i.e., the extent to which reciprocal or defensive violence may account for women's and men's reports of perpetration) and experience of fear. Regarding the context of violence, "for women, frequency of victimization accounted for almost $50 \%$ of the variance in frequency of perpetration, while for men, frequency of victimization accounted for only $12 \%$ of the variance in the frequency of perpetration" (p. 213) With regard to fear, women were more likely to report greater fear than men in response to a dating partner's violence. Given these differences, the researchers call for gender-sensitive approaches to the study of interpersonal violence.

Hypothesis 2 (Feminist hypothesis): Women college students will be more likely to report experiencing physical and psychological abuse by intimate partners than men. 


\subsection{Feminist Disability Theory}

The integration of feminist theory and disability theory would allow for the full exploration of the intersection of gender, disability, and experiences of abuse (Barranti \& Yuen, 2008) and offer a context in which the study of women with disabilities makes sense and informs policy (Gilson, Cramer, \& Depoy, 2001; Jones, 2007; Mays, 2006). Disability when understood as a social construct recognizes that persons with disabilities are marginalized, excluded, or socially invisible (Chenoweth, 1997; Jones, 2007; Mays, 2006; Smith \& Anderson, 2004). Such a social construction puts forth a portrayal of women with disabilities as easily victimized in a double sense-as women and as having a disability (Rousso, 2001). In the same manner as disability theory and feminist theory, women with disabilities face similar barriers identified in those theoretical ways of viewing the world but with the amplification of the dual status of being women and having a disability. Feminist disability theory integrates feminism with its emphasis on the inequalities inherent in the male dominated, patriarchal society and disability theory with the focus on the effects of marginalization and unequal treatment for women who have a disability and suffer from abuse (Barranti \& Yuen, 2008; Fiduccia \& Wolfe, 1999; Garland-Thomson, 2001; Mays, 2006; Rousso, 2001). Recent studies conducted in the U.S. have found that compared to women without disabilities, women with disabilities are more likely to experience intimate partner violence (Brownridge, 2006; Martin et al., 2006) and longer durations of abuse (Nosek, Howland, \& Hughes, 2001). Merely applying traditional theories that focus on male domination and patriarchy to the experiences of abuse suffered by women who also have disabilities has prevented an effective means of addressing these unique problems (Center for Research on Women with Disabilities, 2002; Frantz, Carey, \& Bryen, 2006; Jones, 2007; Mays, 2006).

Hypothesis 3 (Feminist-Disability hypothesis): The interaction effect between gender and disability status will be positively related to reported intimate partner abuse. For this study, the interaction effect would be Deaf and hard of hearing women vs. hearing women, hearing men, and Deaf and hard of hearing men.

Research on IPV among persons with disabilities tends to focus solely on disability as a risk factor, neglecting additional risk factors that may increase the likelihood of partner violence. Previous research with general college samples suggests that living arrangements may be associated with experiencing victimization whereby college students that live independently and off-campus may be more vulnerable than those living with others and on-campus (Lehrer, Lehrer, Lehrer, \& Oyarzua, 2007; Forke et al., 2008). Some research also suggests that race may be associated with experiencing victimization, although studies are inconclusive. For example, some research has found higher rates of interpersonal violence among African Americans when compared to whites (Caetano, Schafer, \& Cunradi, 2001; Makepeace, 1987; Rouse, 1988) while another study found just the opposite (Lane \& Gwartney-Gibbs, 1985). Although not studied extensively, it has also been suggested that participation in sports may protect females 
from victimization in that it develops their strength and self-esteem (Fasting, Brackenridge, \& Sundgot-Borgen, 2003). Research also suggests that international students "may be a group that is especially susceptible to criminal victimization because they may not be well-versed in the English language or assimilated into the American culture. Difficulties of coping with an alien, culturally different population and a general fear of strangers can make foreign students feel helpless and especially vulnerable to crime-thus making them worry about crime happening to them." (Coston, 2007: p. 174).

\subsection{Present Study}

The current study adds to the literature on interpersonal violence between dating partners in several ways. First, we will examine the extent of partner violence victimization among a sample of hearing, Deaf and hard of hearing male and female college students and whether these experiences vary by auditory status. The few studies that examine auditory status in the partner violence literature are often limited to victimization among women and ignore men as victims. By including male and female college students in the analysis, this study is able to explore whether auditory status increases the probability of reporting psychological and/or physical abuse. Second, this will be the first empirical study to use a sample of Deaf and hard of hearing college students to test disability theory, feminist theory and feminist disability theory. This is an important contribution because very little, if anything, has been published about the etiology of IPV for college students that are Deaf or hard of hearing. To offer appropriate services to both survivors and perpetrators of IPV, more specific knowledge of the prevalence and etiology of this phenomenon are warranted. Such information will also facilitate the development of approaches to support and treat those involved in abusive relationships, and create greater public awareness of IPV in the Deaf and hard of hearing community.

\section{Method}

\subsection{Data Collection}

The cross-sectional data for this study was collected from students at the Rochester Institute of Technology (RIT) (http://www.rit.edu/), a northeastern university in the U.S. Forty classes were randomly selected by the researchers. After receiving approval from the Institutional Review Board (IRB) at RIT, surveys were distributed within randomly selected classes to all students. Students were informed that the survey was voluntary and were told that if they had previously filled out a survey they should not fill out the survey again. The survey was distributed in the spring term. A total of 987 students filled out the surveys for a response rate of $98.3 \%$.

We limited our sample to traditional aged students that were 22 or younger. Between removing older students (23 and up) and cases missing data on any of the dependent and independent variables, the final sample size for this study was 816. 
The strength of doing a survey on victimization at RIT is that the university has a sizeable percentage of Deaf and hard of hearing students. The National Technical Institute for the Deaf (NTID) is one of the colleges at the university. Interpreters were available during survey administration in the event that written questions needed clarification.

Within our sample, $17.9 \%$ of the students reported being Deaf or hard of hearing. This percentage was much higher than the percentage of students enrolled in NTID (7.6\%), but was also quite a bit higher than students that reported being enrolled in NTID $(9.7 \%)$ in the sample. It was clear from these results that not all Deaf or hard of hearing students were enrolled in NTID and thus it was hard to determine if our sample is representative, in terms of hearing vs. non-hearing students, of the RIT population. There were some other representativeness issues that should be addressed for these surveys. First, women were slightly overrepresented in the sample. Women were $31 \%$ of the student population. In the sample used for this study, women accounted for about $40 \%$ (40.9\%) of the sample. Secondly, the different colleges at the university were not represented in the sample as they were within the student population. In particular, the College of Liberal Arts was oversampled within the survey. While the survey was not representative of the university at large, the sample does include a good percentage of the students of interest, Deaf and hard of hearing students.

\subsection{Participants}

The sample consisted of 816 respondents, including 482 men (59.1\%) and 334 women (40.9\%) (see Table 1). The majority of the participants $(73.0 \%)$ identified themselves as white. About $82 \%(n=670)$ of the participants identified as hearing, and $17.9 \%(\mathrm{n}=146)$ as Deaf or hard-of-hearing. There were $41(5 \%)$ international students. More than half of the respondents lived on campus $(62.1 \% ; \mathrm{n}=507)$ and less than $10 \%(\mathrm{n}=69)$ lived alone. Only a small percentage of the sample, $17.3 \%(n=141)$, participated in intercollegiate or campus sports.

\subsection{Measures}

The dependent variables for analysis are dichotomous variables measuring presence or absence of abuse and were created from a variety of questions pertaining to various types of victimization. To measure psychological and physical abuse among dating partners within the past school year, Straus et al.'s (1996) Revised Conflict Tactics Scale (CTS2) was used to measure intimate partner violence by "a partner" over the previous school year. Use of the term "partner" denotes intimate partner violence may exist among heterosexual and same-sex partners. The CTS2 is a commonly used measure of intimate partner violence that measures the frequency with which respondents had experienced psychological and physical abuse from their dating partners. Three items assessed psychological abuse: partner insulted or swore at you, partner put you down in front of friends and/or family, and partner threatened to hit/throw something at you (Cronbach's Alpha $=0.479)$. Factor analysis confirmed that the three psy- 
Table 1. Descriptive statistics.

\begin{tabular}{|c|c|c|c|c|c|c|c|c|c|c|}
\hline \multirow[b]{2}{*}{ Variable Name } & \multicolumn{2}{|c|}{$\begin{array}{l}\text { Total Sample } \\
\quad(\mathrm{N}=816)\end{array}$} & \multicolumn{2}{|c|}{ Females $(\mathrm{N}=334)$} & \multicolumn{2}{|c|}{ Males $(\mathrm{N}=482)$} & \multicolumn{2}{|c|}{$\begin{array}{l}\text { Deaf and Hard of } \\
\text { Hearing }(\mathrm{N}=146)\end{array}$} & \multicolumn{2}{|c|}{ Hearing $(N=670)$} \\
\hline & Frequency & Percent & Frequency & Percent & Frequency & Percent & Frequency & Percent & Frequency & Percent \\
\hline \multicolumn{11}{|l|}{ Psychological Abuse } \\
\hline No & 462 & 56.62 & 165 & 49.40 & 297 & 61.62 & 50 & 34.25 & 412 & 61.49 \\
\hline Yes & 354 & 43.38 & 169 & 50.60 & 185 & 38.38 & 96 & 65.75 & 258 & 38.51 \\
\hline \multicolumn{11}{|l|}{ Physical Abuse } \\
\hline No & 610 & 74.75 & 246 & 73.65 & 364 & 75.52 & 78 & 53.42 & 532 & 79.40 \\
\hline Yes & 206 & 25.25 & 88 & 26.35 & 118 & 24.48 & 68 & 46.58 & 138 & 20.60 \\
\hline \multicolumn{11}{|l|}{ Auditory Status } \\
\hline Hearing & 670 & 82.11 & 259 & 77.54 & 411 & 85.27 & --- & --- & --- & --- \\
\hline Deaf and Hard of Hearing & 146 & 17.89 & 75 & 22.46 & 71 & 14.73 & --- & --- & --- & --- \\
\hline \multicolumn{11}{|l|}{ Gender } \\
\hline Male & 482 & 59.07 & --- & --- & --- & --- & 71 & 48.63 & 411 & 61.34 \\
\hline Female & 334 & 40.93 & --- & --- & --- & --- & 75 & 51.37 & 259 & 38.66 \\
\hline \multicolumn{11}{|l|}{ On a Sports Team } \\
\hline No & 675 & 82.72 & 290 & 86.83 & 385 & 79.88 & 118 & 80.82 & 557 & 83.13 \\
\hline Yes & 141 & 17.28 & 44 & 13.17 & 97 & 20.12 & 28 & 19.18 & 113 & 16.87 \\
\hline \multicolumn{11}{|l|}{ International Student } \\
\hline No & 775 & 94.98 & 312 & 93.41 & 463 & 96.06 & 132 & 90.41 & 643 & 95.97 \\
\hline Yes & 41 & 5.02 & 22 & 6.59 & 19 & 3.94 & 14 & 9.59 & 27 & 4.03 \\
\hline \multicolumn{11}{|l|}{ Live on Campus } \\
\hline No & 309 & 37.87 & 140 & 41.92 & 169 & 35.06 & 40 & 27.40 & 269 & 40.15 \\
\hline Yes & 507 & 62.13 & 194 & 58.08 & 313 & 64.94 & 106 & 72.60 & 401 & 59.85 \\
\hline \multicolumn{11}{|l|}{ Live Alone } \\
\hline No & 747 & 91.54 & 309 & 92.51 & 438 & 90.87 & 126 & 86.30 & 621 & 92.69 \\
\hline Yes & 69 & 8.46 & 25 & 7.49 & 44 & 9.13 & 20 & 13.70 & 49 & 7.31 \\
\hline \multicolumn{11}{|l|}{ Race } \\
\hline Non-white & 220 & 26.96 & 116 & 34.73 & 104 & 21.58 & 73 & 50.00 & 147 & 21.94 \\
\hline white & 596 & 73.04 & 218 & 65.27 & 378 & 78.42 & 73 & 50.00 & 523 & 78.06 \\
\hline
\end{tabular}

chological abuse variables appear to be measuring a similar concept (partner insulted or swore at you (0.74), partner put you down in front of friends and/or family (0.69), and partner threatened to hit/throw something at you (0.68)). Seven items assessed physical abuse: partner pushed, grabbed or shoved you, partner slapped you, partner kicked, bit, or shoved you, partner beat you up, partner hit you or tried to hit you with something, partner choked you, and partner threatened you with a gun/knife (Cronbach's Alpha $=0.675)$. The physical abuse variables do not load as nicely on one concept as the psychological abuse variables (partner pushed, grabbed or shoved you (0.65), partner slapped you (0.70), partner kicked, bit, or shoved you (0.70), partner beat you up (0.59), partner hit you or tried to hit you with something (0.53), partner choked you 
(0.51), and partner threatened you with a gun $/$ knife (0.42)). While the factor analysis would suggest a second variable composed of partner choked you and partner threatened you with a gun/knife, there would only be 23 cases in that second physical abuse variable. With only 23 cases and loadings all above. 4 it appeared to be more prudent to include all of the measures of physical abuse into one dichotomous variable. ${ }^{2}$ Subjects responded on a four-point scale (never, 1 - 2 times, 3 - 10 times, more than 10 times). Previous studies using the CTS-2 on Deaf and hard of hearing college students reported sound validity between the psychological and physical abuse scales for these measures (Anderson \& Leigh, 2010).

Auditory status and gender are the two independent variables. Auditory status was measured with the question: "Which best describes your auditory status?" Students were able to answer hearing, hard of hearing, or Deaf. Hard of hearing and Deaf were combined into one category due to small sizes and hearing was the comparison category. Deaf and hard of hearing was coded as 1 and hearing was coded as 0 . Gender was coded as a dichotomous variable where $1=$ women and $0=$ men. As discussed in the introduction, a variety of control variables were included due to prior research that has found a relationship between these variables and victimization (Anderson \& Leigh, 2011; Caetano, Schafer, \& Cunradi, 2001; Fasting, Brackenridge, \& Sundgot-Borgen, 2003; Lane \& GwartneyGibbs, 1985; Lehrer, Lehrer, Lehrer, \& Oyarzua, 2007; Makepeace, 1987; Rouse, 1988). The control variables were all made into dichotomous variables and coded as follows: involvement in sports $(1=$ intercollegiate or campus; $0=$ none); international student ( $1=$ yes; $0=$ no); Live on campus ( $1=$ on campus; $0=$ off campus or other); Live alone $(1=$ alone; 2 = roommate/housemate, or spouse/significant other, parents, and other); Race ( $1=$ White; $0=$ non White). Table 2 presents the mean and standard deviations for the full sample and for subsamples based on gender and auditory status. ${ }^{3}$

The correlation ${ }^{4}$ between psychological abuse and physical abuse is significant for the full sample and for subsamples based on gender. It is slightly stronger in the models for women. The correlation between gender and auditory status is significant, but not strong.

The victimization variables are all dichotomous variables that indicate the presence or absence of abuse. While a scale could have been used since there are three psychological abuse measures and seven physical abuse measures, the main purpose of this study was to see if there was a difference in the reporting of abuse. Dichotomous variables allow for the testing of the presence/absence of each type of abuse. Additionally, the scales had low Cronbach's Alphas, particularly for psychological abuse, and skewed distributions. Binary logistic regression ${ }^{2}$ According to Matsunaga (2010) a loading of 0.4 "is perhaps the lowest acceptable threshold." (p. 101).

${ }^{3}$ MANOVA was used to determine if there were significant differences in the variables by gender. There were significant differences for physical abuse and race. Women were significantly more likely to have reported physical abuse and were less likely to be white than men.

${ }^{4}$ The correlation matrices were not included due to concerns about space. The correlation matrices can be obtained from the authors. 
Table 2. Descriptive statistics.

\begin{tabular}{|c|c|c|c|c|c|c|c|c|c|c|}
\hline \multirow[b]{2}{*}{ Variable Name } & \multicolumn{2}{|c|}{$\begin{array}{l}\text { Total Sample } \\
\qquad(\mathrm{N}=816)\end{array}$} & \multicolumn{2}{|c|}{ Females $(\mathrm{N}=334)$} & \multicolumn{2}{|c|}{ Males $(\mathrm{N}=482)$} & \multicolumn{2}{|c|}{$\begin{array}{l}\text { Deaf and Hard of } \\
\text { Hearing }(N=146)\end{array}$} & \multicolumn{2}{|c|}{ Hearing $(N=670)$} \\
\hline & Mean & $\begin{array}{c}\text { Std. } \\
\text { Deviation }\end{array}$ & Mean & $\begin{array}{c}\text { Std. } \\
\text { Deviation }\end{array}$ & Mean & $\begin{array}{c}\text { Std. } \\
\text { Deviation }\end{array}$ & Mean & $\begin{array}{c}\text { Std. } \\
\text { Deviation }\end{array}$ & Mean & $\begin{array}{c}\text { Std. } \\
\text { Deviation }\end{array}$ \\
\hline Psychological Abuse & 0.43 & 0.50 & 0.51 & 0.50 & 0.38 & 0.49 & 0.66 & 0.48 & 0.39 & 0.49 \\
\hline Physical Abuse & 0.25 & 0.43 & 0.26 & 0.44 & 0.24 & 0.43 & 0.47 & 0.50 & 0.21 & 0.40 \\
\hline Auditory Status & 0.18 & 0.38 & 0.22 & 0.42 & 0.15 & 0.35 & 1.00 & 0.00 & 0.00 & 0.00 \\
\hline Gender Recoded & 0.41 & 0.49 & 1.00 & 0.00 & 0.00 & 0.00 & 0.51 & 0.50 & 0.39 & 0.49 \\
\hline $\begin{array}{c}\text { On a sports team } \\
\text { (Intercollegiate or Campus) }\end{array}$ & 0.17 & 0.38 & 0.13 & 0.34 & 0.20 & 0.40 & 0.19 & 0.40 & 0.17 & 0.37 \\
\hline International Student & 0.05 & 0.22 & 0.07 & 0.25 & 0.04 & 0.19 & 0.10 & 0.30 & 0.04 & 0.20 \\
\hline Lives on Campus & 0.62 & 0.49 & 0.58 & 0.49 & 0.65 & 0.48 & 0.73 & 0.45 & 0.60 & 0.49 \\
\hline Live Alone & 0.08 & 0.28 & 0.07 & 0.26 & 0.09 & 0.29 & 0.14 & 0.35 & 0.07 & 0.26 \\
\hline Whites-Non-White recoded & 0.73 & 0.44 & 0.65 & 0.48 & 0.78 & 0.41 & 0.50 & 0.50 & 0.78 & 0.41 \\
\hline
\end{tabular}

analyses were used to examine the effect of auditory status, gender, and other variables on the two types of victimization. In order to test disability theory, feminist theory and feminist disability theory, four models were examined. Table 3(a) and Table 4(a) test feminist theory. The second set of Table 3(b) and Table 4(b) test feminist disability theory and include an interaction effect between auditory status and gender. This allows for a test of feminist disability theory. Based on feminist disability theory, we predict that Deaf and hard of hearing women will be more likely to report psychological and physical abuse than hearing college students. Table 4(c) and Table 4(c) examine the effects of the independent variables on psychological and physical abuse for men, while Table 4(d) and Table 4(d) limit the sample to women. Multicollinearity does not appear to be an issue for any of the models. The largest variance inflation factor (VIF) in any of the various models was 2.326. Data were analyzed using SPSS version 17 (SPSS Inc., 2008).

\section{Results}

The RIT campus provides a unique opportunity to explore psychological and physical victimization among the Deaf and hard of hearing population by virtue of having the National Institute for the Deaf (NTID) on campus. Tables 3(a)-(d) present the various psychological abuse models and Tables 4(a)-(d) present the various physical abuse models. The first step in the analysis examined if reported psychological and physical abuse are significantly related to auditory status and gender. The first model (all cases) included both auditory status and gender as predictors of reported psychological abuse (Table 3(a)) and reported physical abuse (Table 4(a)). Deaf and hard of hearing students were more likely to have reported psychological and physical abuse. This provides support for disability theory.

Women were more likely to have reported psychological abuse than men, but 
Table 3. (a) Reported victimization outcomes for psychological abuse for all cases. (b) Reported victimization outcomes for psychological abuse for all cases (Interaction effect between gender and auditory status). (c) Reported victimization outcomes for psychological abuse for males. (d) Reported victimization outcomes for psychological abuse for females.

(a)

\begin{tabular}{cccccccccc}
\hline & & & & & & \multicolumn{3}{c}{$\begin{array}{c}95 \% \text { CI } \\
\text { for Exp } \\
\text { (B) }\end{array}$} \\
\hline Independent Variable & B & SE & Wald & df & $p$ & OR & Lower & Upper \\
\hline Auditory Status & $1.10^{* *}$ & 0.20 & 29.95 & 1.00 & 0.00 & 3.01 & 2.03 & 4.46 \\
Gender & $0.39^{*}$ & 0.15 & 6.60 & 1.00 & 0.01 & 1.47 & 1.10 & 1.97 \\
Involved in Sports & -0.25 & 0.20 & 1.57 & 1.00 & 0.21 & 0.78 & 0.53 & 1.15 \\
International Student & 0.26 & 0.36 & 0.53 & 1.00 & 0.47 & 1.30 & 0.64 & 2.65 \\
Lives on Campus & $-0.36^{*}$ & 0.15 & 5.36 & 1.00 & 0.02 & 0.70 & 0.52 & 0.95 \\
Lives Alone & 0.30 & 0.26 & 1.26 & 1.00 & 0.26 & 1.34 & 0.80 & 2.25 \\
Race & -0.06 & 0.18 & 0.10 & 1.00 & 0.76 & 0.94 & 0.66 & 1.35 \\
\hline
\end{tabular}

${ }^{+} p<0.05$ one tailed test. ${ }^{*} p<0.05$ two tailed test. ${ }^{* *} p<0.01$ two tailed test.

(b)

\begin{tabular}{cccccccccc}
\hline & & & & & \multicolumn{4}{c}{$\begin{array}{c}95 \% \text { CI } \\
\text { for } \\
\text { Exp(B) }\end{array}$} \\
\hline Independent Variable & B & SE & Wald & df & $p$ & OR & Lower & Upper \\
\hline Auditory Status & $1.53^{* *}$ & 0.28 & 29.48 & 1.00 & 0.00 & 4.62 & 2.66 & 8.02 \\
Gender & $0.54^{* *}$ & 0.16 & 10.77 & 1.00 & 0.00 & 1.72 & 1.24 & 2.37 \\
Involved in Sports & -0.27 & 0.20 & 1.76 & 1.00 & 0.18 & 0.76 & 0.51 & 1.14 \\
International Student & 0.24 & 0.36 & 0.43 & 1.00 & 0.51 & 1.27 & 0.62 & 2.58 \\
Lives on Campus & $-0.34^{*}$ & 0.15 & 4.97 & 1.00 & 0.03 & 0.71 & 0.52 & 0.96 \\
Lives Alone & 0.30 & 0.26 & 1.30 & 1.00 & 0.25 & 1.35 & 0.81 & 2.27 \\
Race & -0.10 & 0.18 & 0.29 & 1.00 & 0.59 & 0.91 & 0.63 & 1.30 \\
Gender*Auditory & $-0.90^{*}$ & 0.39 & 5.23 & 1.00 & 0.02 & 0.41 & 0.19 & 0.88 \\
Status & & & & & & & & \\
\hline
\end{tabular}

${ }^{+} p<0.05$ one tailed test. ${ }^{*} p<0.05$ two tailed test. ${ }^{*} p<0.01$ two tailed test.

(c)

\begin{tabular}{cccccccccc}
\hline & & & & & \multicolumn{4}{c}{$\begin{array}{c}9 \% \text { CI } \\
\text { for } \\
\text { Exp(B) }\end{array}$} \\
\hline Independent Variable & B & SE & Wald & df & $p$ & Exp(B) & Lower & Upper \\
\hline Auditory Status & $1.57^{* *}$ & 0.29 & 30.17 & 1.00 & 0.00 & 4.79 & 2.74 & 8.37 \\
Involved in Sports & -0.29 & 0.25 & 1.31 & 1.00 & 0.25 & 0.75 & 0.46 & 1.23 \\
International Student & -0.07 & 0.55 & 0.02 & 1.00 & 0.89 & 0.93 & 0.32 & 2.71 \\
Lives on Campus & $-0.46^{*}$ & 0.21 & 4.92 & 1.00 & 0.03 & 0.63 & 0.42 & 0.95 \\
Lives Alone & 0.07 & 0.34 & 0.04 & 1.00 & 0.85 & 1.07 & 0.55 & 2.09 \\
Race & -0.16 & 0.25 & 0.41 & 1.00 & 0.52 & 0.85 & 0.52 & 1.40 \\
\hline
\end{tabular}

${ }^{+} p<0.05$ one tailed test. ${ }^{*} p<0.05$ two tailed test. ${ }^{* *} p<0.01$ two tailed test. 
(d)

\begin{tabular}{ccccccccc}
\hline & & & & & \multicolumn{4}{c}{$\begin{array}{c}95 \% \text { CI } \\
\text { for } \\
\text { Exp(B) }\end{array}$} \\
\hline Independent Variable & B & SE & Wald & df & $p$ & Exp(B) & Lower & Upper \\
\hline Auditory Status & $0.57^{+}$ & 0.29 & 3.79 & 1.00 & 0.05 & 1.77 & 1.00 & 3.15 \\
Involved in Sports & -0.30 & 0.34 & 0.75 & 1.00 & 0.39 & 0.74 & 0.38 & 1.46 \\
International Student & 0.50 & 0.50 & 1.02 & 1.00 & 0.31 & 1.65 & 0.62 & 4.39 \\
Lives on Campus & -0.19 & 0.24 & 0.62 & 1.00 & 0.43 & 0.83 & 0.52 & 1.32 \\
Lives Alone & $0.75^{+}$ & 0.45 & 2.77 & 1.00 & 0.10 & 2.12 & 0.87 & 5.14 \\
Race & -0.07 & 0.27 & 0.08 & 1.00 & 0.78 & 0.93 & 0.55 & 1.56 \\
\hline
\end{tabular}

${ }^{+} p<0.05$ one tailed test. ${ }^{*} p<0.05$ two tailed test. ${ }^{* *} p<0.01$ two tailed test.

not physical abuse. Due to the mixed results for gender, feminist theory gained only mixed support. Not surprisingly, living on campus reduced reported psychological abuse and physical abuse. None of the other control variables had an impact on reported victimization for either type of abuse.

Table 3(b) and Table 4(b) (All cases) included an interaction effect between auditory status and gender. College students that were Deaf or hard of hearing and women received a score of 1 (Deaf or hard of hearing was coded 1 on auditory status and women was coded 1 on gender thus multiplying the two together gave Deaf or hard of hearing women a 1 and everyone else a 0 ). The results for the model with the interaction effect mirror those from the model without the interaction effect. Auditory status still increased reported psychological and physical abuse, with Deaf and hard of hearing students more likely to report abuse than hearing students. Gender only affected the reporting of psychological abuse, with women more likely to report such abuse than men. The only control variable that had an impact on reported victimization was once again living on campus. However, the interaction effect is negative and significant, the opposite of what feminist disability theory would predict. This would indicate that not only were Deaf or hard of hearing women not more likely to report victimization, but in this sample being Deaf or hard of hearing and female actually had a somewhat protective effect compared to what would be predicted from using just auditory status and gender. The more surprising part of these results is that gender does not have an effect on reported physical abuse, but when an interaction effect is included, we see that Deaf or hard of hearing women were less likely to report physical abuse than would be predicted based on auditory status and gender alone with no interaction effect included in the model. Feminist disability theory received no support from our analysis.

In order to get a better understanding of the interplay between auditory status and gender and their effects on psychological and physical abuse, binary logistic regressions for men and women were examined. Deaf and hard of hearing men (see Table 3(c) and Table 4(c)) were much more likely to report both psychological and physical abuse than hearing men. In fact for men, the effect of auditory 
Table 4. (a) Reported victimization outcomes for physical abuse for all cases. (b) Reported victimization outcomes for physical abuse for all cases (interaction effect between gender and auditory status). (c) Reported victimization outcomes for physical abuse for males. (d) Reported victimization outcomes for physical abuse for females.

(a)

\begin{tabular}{|c|c|c|c|c|c|c|c|c|}
\hline & & & & & & & $\begin{array}{c}95 \% \text { CI } \\
\text { for } \\
\operatorname{Exp}(B)\end{array}$ & \\
\hline Independent Variable & B & SE & Wald & df & $p$ & OR & Lower & Upper \\
\hline Auditory Status & $1.24^{* *}$ & 0.20 & 37.02 & 1.00 & 0.00 & 3.46 & 2.32 & 5.16 \\
\hline Gender & -0.01 & 0.17 & 0.01 & 1.00 & 0.94 & 0.99 & 0.70 & 1.38 \\
\hline Involved in Sports & 0.21 & 0.22 & 0.91 & 1.00 & 0.34 & 1.23 & 0.80 & 1.90 \\
\hline International Student & 0.55 & 0.38 & 2.11 & 1.00 & 0.15 & 1.73 & 0.83 & 3.62 \\
\hline Lives on Campus & $-0.40^{*}$ & 0.18 & 5.08 & 1.00 & 0.02 & 0.67 & 0.48 & 0.95 \\
\hline Lives Alone & 0.45 & 0.28 & 2.54 & 1.00 & 0.11 & 1.56 & 0.90 & 2.70 \\
\hline Race & 0.09 & 0.21 & 0.17 & 1.00 & 0.68 & 1.09 & 0.72 & 1.64 \\
\hline
\end{tabular}

${ }^{+} p<0.05$ one tailed test. ${ }^{*} p<0.05$ two tailed test. ${ }^{* *} p<0.01$ two tailed test.

(b)

\begin{tabular}{|c|c|c|c|c|c|c|c|c|}
\hline & & & & & & & $\begin{array}{c}95 \% \mathrm{CI} \\
\text { for } \\
\operatorname{Exp}(\mathrm{B})\end{array}$ & \\
\hline Independent Variable & B & SE & Wald & df & $p$ & OR & Lower & Upper \\
\hline Auditory Status & $1.78^{\star \star}$ & 0.28 & 41.27 & 1.00 & 0.00 & 5.92 & 3.44 & 10.18 \\
\hline Gender & 0.27 & 0.20 & 1.89 & 1.00 & 0.17 & 1.31 & 0.89 & 1.92 \\
\hline Involved in Sports & 0.19 & 0.22 & 0.74 & 1.00 & 0.39 & 1.21 & 0.78 & 1.88 \\
\hline International Student & 0.51 & 0.38 & 1.81 & 1.00 & 0.18 & 1.66 & 0.79 & 3.49 \\
\hline Lives on Campus & $-0.38^{\star}$ & 0.18 & 4.57 & 1.00 & 0.03 & 0.69 & 0.48 & 0.97 \\
\hline Lives Alone & 0.46 & 0.28 & 2.66 & 1.00 & 0.10 & 1.59 & 0.91 & 2.76 \\
\hline Race & 0.02 & 0.21 & 0.01 & 1.00 & 0.94 & 1.02 & 0.67 & 1.53 \\
\hline $\begin{array}{c}\text { Gender }{ }^{*} \text { Auditory } \\
\text { Status }\end{array}$ & $-1.16^{\star *}$ & 0.40 & 8.50 & 1.00 & 0.00 & 0.31 & 0.14 & 0.68 \\
\hline
\end{tabular}

${ }^{+} p<0.05$ one tailed test. ${ }^{*} p<0.05$ two tailed test. ${ }^{* *} p<0.01$ two tailed test.

(c)

\begin{tabular}{|c|c|c|c|c|c|c|c|c|}
\hline & & & & & & & $\begin{array}{l}95 \% \text { CI } \\
\text { for } \\
\operatorname{Exp}(B)\end{array}$ & \\
\hline Independent Variable & B & SE & Wald & df & $p$ & $\operatorname{Exp}(B)$ & Lower & Upper \\
\hline Auditory Status & $1.85^{\star *}$ & 0.28 & 42.93 & 1.00 & 0.00 & 6.38 & 3.67 & 11.11 \\
\hline Involved in Sports & -0.03 & 0.28 & 0.01 & 1.00 & 0.92 & 0.97 & 0.56 & 1.70 \\
\hline International Student & 0.34 & 0.59 & 0.33 & 1.00 & 0.56 & 1.41 & 0.44 & 4.51 \\
\hline Lives on Campus & $-0.58^{\star}$ & 0.24 & 5.86 & 1.00 & 0.02 & 0.56 & 0.35 & 0.90 \\
\hline Lives Alone & 0.53 & 0.37 & 2.09 & 1.00 & 0.15 & 1.70 & 0.83 & 3.49 \\
\hline Race & 0.16 & 0.30 & 0.29 & 1.00 & 0.59 & 1.18 & 0.65 & 2.12 \\
\hline
\end{tabular}

${ }^{+} p<0.05$ one tailed test. ${ }^{*} p<0.05$ two tailed test. ${ }^{* *} p<0.01$ two tailed test. 
(d)

\begin{tabular}{|c|c|c|c|c|c|c|c|c|}
\hline & & & & & & & $\begin{array}{c}95 \% \text { CI } \\
\text { for } \\
\operatorname{Exp}(B)\end{array}$ & \\
\hline Independent Variable & B & SE & Wald & df & $p$ & $\operatorname{Exp}(B)$ & Lower & Upper \\
\hline Auditory Status & 0.51 & 0.31 & 2.66 & 1.00 & 0.10 & 1.66 & 0.90 & 3.05 \\
\hline Involved in Sports & 0.51 & 0.37 & 1.92 & 1.00 & 0.17 & 1.66 & 0.81 & 3.40 \\
\hline International Student & 0.56 & 0.50 & 1.27 & 1.00 & 0.26 & 1.75 & 0.66 & 4.61 \\
\hline Lives on Campus & -0.17 & 0.27 & 0.38 & 1.00 & 0.54 & 0.85 & 0.50 & 1.44 \\
\hline Lives Alone & 0.45 & 0.45 & 1.01 & 1.00 & 0.31 & 1.57 & 0.65 & 3.78 \\
\hline Race & -0.18 & 0.30 & 0.37 & 1.00 & 0.54 & 0.83 & 0.46 & 1.50 \\
\hline
\end{tabular}

${ }^{+} p<0.05$ one tailed test. ${ }^{*} p<0.05$ two tailed test. ${ }^{*} p<0.01$ two tailed test.

status is quite large for reporting both types of abuse. Deaf and hard of hearing men were almost 5 times more likely to report psychological abuse $(\mathrm{OR}=4.79)$ and over 6 times more likely to report physical abuse $(\mathrm{OR}=6.38)$. This finding supports disability theory for men. Men with a disability, in this case their auditory status, were more likely to report psychological abuse and physical abuse than hearing men.

For women (see Table 3(d) and Table 4(d)), auditory status was not nearly as relevant for their levels of reported victimization. Women that were Deaf and hard of hearing were a little over $70 \%$ more likely to report psychological abuse than hearing women. However, this relationship only exists at the 0.10 level. For physical abuse, there was no difference between the levels of reporting between auditory status categories. Unlike for men, women's victimization appears to be less affected by their auditory status. The driving force for reported victimization for women seems to be their gender. When gender was included as an independent variable (Table 3(a) and Table 4(a)), women and the Deaf and hard of hearing were more likely to report psychological abuse and only auditory status had an impact on the levels of reported physical abuse. However, when we look at only women in the sample, auditory status is barely significant for psychological abuse and not significant for physical abuse. This lends limited support to feminist theory; being a woman seems to be the most important factor in determining women's experiences of victimization, at least for psychological abuse.

\section{Discussion}

Of the three theories tested, only disability theory received strong support. Regardless of the type of victimization, psychological or physical, auditory status had a significant impact on reported victimization for college students. If we use the results from the model with all cases and no interaction effect from Table 3(a) and Table 4(a), we see that students that were Deaf or hard of hearing were 3 times more likely to report both psychological and physical abuse than hearing students. These findings are consistent with previous studies that have found 
that Deaf and hard of hearing students are significantly more likely to report abuse than their hearing peers (Anderson \& Leigh, 2010; Porter \& McQuiller Williams, 2011a; Porter \& McQuiller Williams, 2011b), and highlight the importance for education among groups about their varying risks for different types of abuse. Students who are Deaf or hard of hearing, for example, may be exposed to "disability-specific forms of violence" by partners, such as destruction of communication devices (Powers et al., 2009: p. 1041), isolation manifested by checking the victim's communication devices, or may include an abuser "insulting the victim by calling her [or him] 'hearing' or making fun of her [or his] ASL [American Sign Language] skills" (Anderson et al., 2011: p. 204). These coercive tactics are used to further isolate and control Deaf victims and may make them less likely to seek help both psychologically and physically through the use of communication devices (Powers et al., 2009). Although our analysis does not indicate why Deaf and hard of students are more likely to report physical partner abuse and psychological partner abuse than hearing students, it has been suggested that Deaf and hard of hearing students in particular have "historically lacked access to comprehensive health and sex information" (Anderson \& Kobek Pezzarossi, 2012: p. 276) and given limited information from their parents and teachers often "rely on their peers to obtain healthand-sex related information" (Anderson \& Kobek Pezzarossi, 2012, p. 276 citing Fitz-Gerald and Fitz-Gerald, 1985; Job, 2004; Swartz, 1993). Accordingly, the heightened levels of psychological and physical abuse among Deaf and hard of hearing college students may be explained in part by limited intimate partner violence health literacy.

On the other hand, feminist theory was supported only for psychological abuse. Women were 1.47 times more likely to report psychological abuse than men. There was no relationship between gender and reporting physical abuse. Previous studies typically explored college women's experiences with victimization, although a growing literature has examined the victimization experiences of college men (Avant et al., 2010; Forke et al., 2008; Hines \& Saudino, 2003). Consistent with previous research (Forke et al., 2008; Hines \& Saudino, 2003), prevalence of physical abuse by a partner is similar for men and women. Thus, in terms of overall prevalence intimate partner physical victimization appears to be fairly gender symmetrical. Such results, however, should be viewed with caution in that the contextual factors (i.e., self-defense, level of injury, or initiator of violence) were not assessed (Dobash \& Dobash, 2004; Saunders, 2002). Studies that have examined contextual factors have found that partner violence is gendered in nature (Archer, 2000; Anderson, 2002; Cercone et al., 2005). For example, Archer's (2000) meta-analysis of the Conflict Tactics Scale-2 (CTS2; Straus, Hamby, Boney-McCoy, \& Sugarman, 1996) found women were more likely to use physical aggression toward a partner than men, although women were more likely to be injured and more likely to receive medical treatment than men. Accordingly, future research is needed concerning specific episodes of physical abuse to learn more about the dynamics of such abuse. For example, for violence 
between dating partners, such research could examine the process, precipitating circumstances, and motivation underlying the violence. A better understanding of these mechanisms might provide a clearer picture of the reasons for victimization and variations among men and women.

One possible explanation for why females were more likely to report psychological abuse, but not physical abuse, than males could be that psychological abuse precedes physical abuse in many situations. Due to our sample being traditional aged students $(18-22)$, many of the relationships reported could very well have been in their early stages and thus psychological abuse could be more prevalent. There is the possibility that longer relationships would see more of a gender effect. While this is speculation, Karakurt and Silver (2013) note that psychological abuse often occurs prior to the physical abuse.

Moreover, the lack of a gender effect for physical violence may be a result of the skewed gender ratio at RIT. Women may have more options to choose from amongst the male population and thus are better able to avoid abusive relationships. Guttentag and Secord (1983) argue that when women are scarce and men are plentiful, men will be less likely to harass or assault women. Women college students at RIT may be less likely to be victimized by intimate partners because they are able to be more selective of partners or because the sex ratio leads men to be more protective of women. We should mention that sex ratio research is mixed on the effect of the sex ratio on victimization. The results for this study may not be indicative of women victimization at universities where the sex ratio is more equal or where there are more women than men. For example, while discussing racial patterns in sexual behavior, Harawa et al. (2003) argued that Black women might have been more likely to "lower their expectations of a boyfriend or husband's behavior, including an expectation of monogamy" (p. 187) due to a skewed sex ratio (more women than men). One caveat should be mentioned when discussing the effects of sex ratio on reported victimization. While a skewed sex ratio may help explain less reported physical abuse, women still reported significantly higher levels of psychological abuse. Thus, while sex ratio may help explain the lack of an effect of gender on reported physical abuse, it may not have the same impact on reported psychological abuse. Although, as stated above, there is the possibility that victims of psychological abuse may be more likely to leave before the abuse gets physical if they are more selective due to the imbalanced sex ratio.

The surprising finding was from the interaction effects in Table $3(\mathrm{~b})$ and Table 4(b). The test for feminist disability theory not only did not support the theory, but found the exact opposite of what the theory would predict. There may be something about RIT that helps reduce isolation, reduce feelings of powerlessness, or improves access to resources for Deaf and hard of hearing women students. The National Technical Institute for the Deaf (NTID) is one of the colleges on the RIT campus. NTID may be effective in reaching out to the Deaf and hard of hearing women. This may provide the female students with a sense of community, help them build friendships, or simply provide them with some- 
where they feel safe they can go if they need someone to speak with about problems. To further support the idea that Deaf and hard of hearing female students may be benefited, in terms of victimization, by NTID would be the findings that living alone did not increase female Deaf and hard of hearing reports of physical and psychological abuse, but did increase the reported physical and psychological abuse for hearing women. ${ }^{5}$ Once again, our results may be indicative of something that is different about RIT than other universities. However, the results suggest that there are ways that universities can help students reduce their victimization. In this case, NTID may be beneficial to the female Deaf and hard of hearing population. While our findings suggest deaf women may be protected by NTID, it is possible similar types of institutes could be created at other universities to help build a sense of community for students with disabilities of all genders.

One important finding that should be examined in future research on the effect of disabilities on victimization was the finding that the effect of auditory status on reported victimization differs by gender. Men that were Deaf and hard of hearing had significantly higher levels of reported psychological and physical abuse. However, women that were Deaf and hard of hearing were more likely to report psychological abuse but were not more likely to report physical abuse than hearing women. Even though Deaf and hard of hearing women were more likely to report psychological abuse, it was not nearly as strong an effect as that for Deaf and hard of hearing men. Consistent with previous research (Porter \& McQuiller Williams, 2011b), this suggests that disability has a different impact on victimization rates for men and women. Disability theory seems to be supported for men, but not for women. For women, their gender appears to be the driving force for victimization even above and beyond their disability. Future studies should examine how different disabilities affect victimization rates within genders. Are women's victimization rates less affected by their personal characteristics than men? Based on our findings, this appears to be the case with auditory status.

Future studies might benefit from a multi-campus approach. If feminist theory and feminist disability theory were not supported in this study because of the demographics (sex ratio) or the presence of NTID then perhaps another study's findings would have been somewhat dependent on the particular university's demographics or institutional settings. A study that looks at multiple universities or colleges could help in removing any biases inherent in one university or college. Another advantage may be a larger number of students with disabilities in the study that may present a wider array of disabilities. If one were to look at four or five universities, then one might be able to get a large enough sample of students with disabilities for analysis. The current study was limited to Deaf and hard of hearing students in part because of the presence of NTID on the RIT campus and thus, there was a significant number of Deaf and hard of hearing students in the sample. Additionally, this study sought to explore the experiences

\footnotetext{
${ }^{5}$ Tables not included in the manuscript but available upon request.
} 
of the Deaf and hard of hearing students at RIT and NTID in order to ensure their well-being. Another advantage of multi-campus research would be that the sex ratio could be a variable of interest if enough campuses were surveyed. With only one campus, we can only speculate that women at RIT were not found to report more physical victimization due to a skewed sex ratio.

\section{References}

Anderson, K. (1997). Gender, Status, and Domestic Violence: An Integration of Feminist and Family Violence Approaches. Journal of Marriage and the Family, 59, 655-559. https://doi.org/10.2307/353952

Anderson, K. L. (2002). Perpetrator or Victims? Relationship between Intimate Partner Violence and Well-Being. Journal of Marriage and Family, 64, 851-863. https://doi.org/10.1111/j.1741-3737.2002.00851.x

Anderson, M. (2014). Intimate Partner Violence in the Deaf Community. 5 Things You Need to Know \& 5 Things You Can Do. Psychiatry Information in Brief, 11, 1-3. http://escholarship.umassmed.edu/pib/vol11/iss1/

Anderson, M. L. (2010). Prevalence and Predictors of Intimate Partner Violence Victimization in the Deaf Community (Unpublished Doctoral Dissertation). Washington DC: Gallaudet University.

Anderson, M. L., \& Leigh, I. W. (2010). Internal Consistency and Factor Structure of the Revised Conflict Tactics Scales in a Sample of Deaf Female College Students. Journal of Family Violence, 25, 475-483. https://doi.org/10.1007/s10896-010-9308-6

Anderson, M. L., \& Leigh, I. W. (2011). Intimate Partner Violence against Deaf Female College Students. Violence against Women, 17, 822-834. http://journals.sagepub.com/doi/pdf/10.1177/1077801211412544

Anderson, M. L., Leigh, I. W., \& Samar, V. J. (2011). Intimate Partner Violence against Deaf Women: A Review. Aggression and Violent Behavior, 16, 200-206. https://doi.org/10.1016/j.avb.2011.02.006

Anderson, M. L., \& Kobek Pezzarossi, C. M. (2012). Is It Abuse? Deaf Female Undergraduates' Labeling of Partner Violence. Journal of Deaf Studies and Deaf Education, 17, 273-286. https://doi.org/10.1093/deafed/enr048

Aosved, A. C., \& Long, P. J. (2005). College Women's Experiences of Psychological Maltreatment and Sexual Assault. Violence and Victims, 20, 577-587. https://doi.org/10.1891/0886-6708.2005.20.5.577

Archer, J. (2000). Sex Difference in Aggression between Heterosexual Partners: A MetaAnalytic Review. Psychological Bulletin, 126, 651-680. https://doi.org/10.1037//0033-2909.126.5.651

Atkinson, K., Greenstein, T., \& Lang, M. (2005). For Women, Breadwinning Can Be Dangerous: Gendered Resource Theory and Wife Abuse. Journal of Marriage and the Family, 67, 1137-1148. https://doi.org/10.1111/j.1741-3737.2005.00206.x

Avant, E. M., Swopes, R. M., Davis, J. L., \& Elhai, J. D. (2010). Psychological Abuse and Posttraumatic Stress Symptoms in College Students .Journal of Interpersonal Violence, 26, 3080-3097. https://doi.org/10.1177/0886260510390954

Barranti, C. C., \& Yuen, F. K. (2008). Intimate Partner Violence and Women with Disabilities: Toward Bringing Visibility to an Unrecognized Population. Journal of Social Work: Disability and Rehabilitation, 7, 115-130.

https://doi.org/10.1080/15367100802081169

Basile, K., Hall, J., \& Walters, M. (2013). Expanding Resource Theory and Femin- 
ist-Informed Theory to Explain Intimate Partner Perpetration by Court-Order Men. Violence against Women, 19, 848-880. https://doi.org/10.1177/1077801213497105

Brownlie, E., Jabbar, A., Beitchman, J., Vida, R., \& Atkinson, L. (2007). Language Impairment and Sexual Assault of Girls and Women: Findings from a Community Sample. Journal of Abnormal Child Psychology, 35, 618-626.

https://doi.org/10.1007/s10802-007-9117-4

Brownmiller, S. (1975). Against Our Will. New York, NY: Simon \& Schuster.

Brownridge, D. A. (2006). Partner Violence against Women with Disabilities. Violence against Women, 12, 805-822.

Brownridge, D. A. (2009). Violence against Women: Vulnerable Populations. New York, NY: Routledge.

Brownridge, D. A., Ristock, J., \& Hiebert-Murphy, D. (2008). The High Risk of IPV against Canadian Women with Disabilities. Medical Science Monitor, 14, PH27-PH32. https://www.ncbi.nlm.nih.gov/pubmed/18443559

Burt, M. (1980). Cultural Myths and Supports for Rape. Journal of Personality and Social Psychology, 38, 217-230. https://doi.org/10.1037/0022-3514.38.2.217

Center for Research on Women with Disabilities (CROWD) (2002). Violence against Women with Physical Disabilities: Final Report Submitted to the Centers for Disease Control and Prevention (Award Reference NO. R04 = CCR614142). Houston, TX: Baylor College of Medicine, Department of Physical Medicine and Rehabilitation. https://www.bcm.edu/research/centers/research-on-women-with-disabilities/topics/vio lence/final-report

Caetano, R., Schafer, J., \& Cunradi, C. B. (2001). Alcohol-Related Intimate Partner Violence among White, Black, and Hispanic Couples in the United States. Alcohol Research and Health, 25, 58-65.

Cercone, J. J., Beach, S. R., \& Arias, I. (2005). Gender Symmetry in Dating Intimate Partner Violence: Does Similar Behavior Imply Similar Constructs. Violence and Victims, 20, 207-218. https://doi.org/10.1891/0886-6708.2005.20.2.207

Chenoweth, L. (1997). Violence and Women with Disabilities: Silence and Paradox. Violence against Women, 2, 391-411. https://doi.org/10.1177/1077801296002004004

Claes, J. A., \& Rosenthal, D. M. (1990). Men Who Batter Women: A Study in Power. Journal of Family Violence, 5, 215-224. https://doi.org/10.1007/BF00980817

Collins, K. S., Schoen, C., Joseph, S., Duchon, L., Simantov, E., \& Yellowitz, M. (1999). Health Concerns across a Woman's Lifespan: The Commonwealth Fund 1998 Survey of Women's Health.

http://www.commonwealthfund.org/usr doc/Healthconcerns surveyreport.pdf

Coston, C. T. M. (2007). Worries about Crime among Foreign Students Studying in the United States: A Comparative Study. In Charise Tia Maria Coston (Ed.), Victimizing Vulnerable Groups: Images of Uniquely High-Risk Crime Targets (pp. 173-193). Westport, CT: Praeger Publishers.

DeKeseredy, W. S., \& Schwartz, M. D. (1998). Woman Abuse on Campus: Results from the Canadian National Survey. Thousand Oaks, CA: Sage.

Depoy, E., Gilson, S., \& Cramer, E. (2003). Understanding the Experiences of and Advocating for the Service and Resource Needs of Abused, Disabled Women. In A. Hans, \& A. Prati (Eds.), Women, Disability, and Identity (pp. 177-187). London: Sage.

Dobash, R. P., \& Dobash, R. E. (2004). Women's Violence in Intimate Relationships: Working on a Puzzle. British Journal of Criminology, 44, 324-349. https://doi.org/10.1093/bjc/azh026

Dobash, R. E., \& Dobash, R. P. (1979). Violence against Wives: A Case against the Pa- 
triarchy. New York, NY: Free Press.

Dobash, R. E., Dobash, R. P., Wilson, M., \& Daly, M. (1992). The Myth of Sexual Symmetry in Martial Violence. Social Problems, 39, 71-91. https://doi.org/10.2307/3096914

Dutton, D. G., \& Nicholls, T. L. (2005). The Gender Paradigm in Domestic Violence Research and Theory: Part 1-The Conflict of Theory and Data. Aggression and Violent Behavior, 10, 680-714. https://doi.org/10.1016/j.avb.2005.02.001

Fasting, K., Brackenridge, C. H., \& Sungot-Borgen, J. (2003). Experiences of Sexual Harassment and Abuse amongst Norwegian Elite Female Athletes and Non-Athletes. Research Quarterly for Exercise and Sport, 74, 84-97. https://doi.org/10.1080/02701367.2003.10609067

Fiduccia, B. F. W., \& Wolfe, L. (1999). Women and Girls with Disabilities: Defining the Issues (The Barbara Waxman Fiduccia Papers on Women and Girls with Disabilities). Washington DC: Center for Women Policy Studies. http://www.centerwomenpolicy.org/programs/waxmanfiduccia/documents/DIS1.pdf

Forke, C. M., Myers, R. K., Catallozzi, M., \& Schwartz, D. F. (2008). Relationship Violence among Women and Male College Undergraduate Students. Archives of Pediatrics \& Adolescent Medicine, 161, 634-641. https://doi.org/10.1001/archpedi.162.7.634

Franklin, C. A., \& Menaker, T. A. (2014). Feminism, Status Inconsistency, and Women's Intimate Partner Victimization in Heterosexual Relationships. Violence against Women, 20, 1-21. https://doi.org/10.1177/1077801214543385

Frantz, B. L., Carey, A. C., \& Bryen, D. N. (2006). Accessibility of Pennsylvania's Victim Assistance Programs. Journal of Disability Policy Studies, 16, 209- 219. https://doi.org/10.1177/10442073060160040201

Garland-Thomson, R. (2001). Re-Shaping, Re-Thinking, Re-Defining: Feminist Disability Studies (The Barbara Waxman Fiduccia Papers on Women and Girls with Disabilities). Washington DC: Center for Women Policy Studies. http://www.centerwomenpolicy.org/pdfs/dis2.pdf

Gelles, R. J. (1974). The Violent Home: A Study of Physical Aggression between Husbands and Wives. Beverly Hills, CA: Sage.

Gilson, S. F., Cramer, E. P., \& De Poy, E. (2001). (Re)Defining Abuse among Women with Disabilities: Enlarging the Scope. Affilia: Journal of Women and Social Work, 16, 220-235. https://doi.org/10.1177/08861090122094235

Guttentag, M, \& Secord, P. F. (1983). Too Many Women? The Sex Ratio Question. Beverly Hills, CA: Sage.

Hague, G., Thiara, R. K., \& Magowan, P. (2007). Disabled Women and Domestic Violence: Making the Links. Interim Report for Women's Aid Federation of England. http://www.equation.org.uk/wp-content/uploads/2016/02/EQ-LIB-126.pdf

Hague, G., Thiara, R. K., Magowan, P., \& Mullender, A. (2008). Making the Links: Disabled Women and Domestic Violence. Summary of Findings and Recommendations for Good Practice Women's Aid Federation of England. http://www.equation.org.uk/wp-content/uploads/2016/02/EQ-LIB-127.pdf

Harawa, N. T., Greenland, S., Cochran, S. D., Cunningham, W. E., \& Visscher, B. (2003). Do Differences in Relationship and Partner Attributes Explain Disparities in Sexually Transmitted Disease among Young White and Black Women? Journal of Adolescent Health, 32, 187-191. https://doi.org/10.1016/S1054-139X(02)00458-5

Harned, M. S. (2001). Abused Women or Abused Men? An Examination of the Context and Outcomes of Dating Violence. Violence and Victims, 16, 269-285.

Harrell, E. (2011). Crime against Persons with Disabilities, 2008-2010-Statistical Tables. Washington DC: National Crime Victimization Survey, U.S. Department of Justice, 
Office of Justice Programs, Bureau of Justice Statistics.

http://www.ncdsv.org/images/BJS CrimesAgainstPersonsWithDisabilities2008-2010St atisticalTables 10-2011.pdf

Hines, D. A., \& Saudino, K. J. (2003). Gender Differences in Psychological, Physical, and Sexual Aggression among College Students Using the Revised Conflict Tactics Scales. Violence and Victims, 18, 197-217. https://doi.org/10.1891/vivi.2003.18.2.197

Howe, K. (2000). Violence against Women with Disabilities: An Overview of the Literature. http://wwda.org.au/issues/viol/viol1995/keran/

Karakurt, G., \& Silver, K. E. (2013). Emotional Abuse in Intimate Relationships: The Role of Gender and Age. Violence and Victims, 28, 804-821. https://doi.org/10.1891/0886-6708.VV-D-12-00041

Job, J. (2004). Factors Involved in the Ineffective Dissemination of Sexuality Information to Individuals Who Are Deaf or Hard of Hearing. American Annals of the Deaf, 149, 264-273. https://doi.org/10.1353/aad.2004.0025

Jones, D. (2007). Domestic Violence against Women with Disabilities: A Feminist Legal Theory Analysis. Florida $A$ \& $M$ University Law Review, 2, Article 6. http://lawlib.wlu.edu/CLJC/index.aspx? mainid=1397\&issuedate $=2008-10-21$

Johnson, A. G. (2005). The Gender Knot: Unraveling Our Patriarchal Legacy. Philadelphia, PA: Temple University Press.

Johnston-McCabe, P., Levi-Minzi, M., Van Hassely, V. B., \& Vanderbeek, A. (2011). Domestic Violence and Clinical Support in a Clinical Sample of Deaf and Hard of Hearing Women. Journal of Family Violence, 26, 63-69. https://doi.org/10.1007/s10896-010-9342-4

Knutson, J. F., Johnson, C. R., \&. Sullivan, P. M. (2004). Disciplinary Choices of Mothers of Deaf Children and Mothers of Normally Hearing Children. Child Abuse \& Neglect, 28, 925-937. https://doi.org/10.1016/j.chiabu.2004.04.005

Lane, K. E., \& Gwartney-Gibbs, P. A. (1985). Violence in the Context of Dating and Sex. Journal of Family Issues, 6, 45-59. https://doi.org/10.1177/019251385006001004

Lehrer, J. A., Lehrer, V. L., Lehrer, E. L., \& Oyarzun, P. B. (2007). Prevalence of and Risk Factors for Sexual Victimization in College Women in Chile. International Family Planning Perspectives, 33, 168-175. https://doi.org/10.1363/ifpp.33.168.07

Lorber, J. (2001). Gender Inequality: Feminist Theories and Politics (2nd ed.). Los Angeles, CA: Roxbury.

Luthra, R., \& Gidycz, C. A. (2006). Dating Violence among College Men and Women: Evaluation of a Theoretical Model. Journal of Interpersonal Violence, 21, 717-731.

Macmillan, R., \& Gartner, R. (1999). When She Brings Home the Bacon: Labor-Force Participation and the Risk of Spousal Violence against Women. Journal of Marriage and Family, 61, 947-958. https://doi.org/10.2307/354015

Makepeace, J. M. (1987). Social Factors and Victim Offender Differences in Courtship Violence. Family Relations, 36, 87-91. https://doi.org/10.2307/584654

Martin, S., Ray, N., Sotres-Alvarez, D., Kupper, L., Moracco, K., Dickens, P., Scandlin, D. et al. (2006). Physical and Sexual Assault of Women with Disabilities. Violence against Women, 12, 823-837. https://doi.org/10.1177/1077801206292672

Mason, T. C. (2010). Does Knowledge of Dating Violence Keep Deaf College Students at Gallaudet University out of Abusive Relationships? Journal of American Deafness \& Rehabilitation Association, 43, 74-91.

Matsunaga, M. (2010). How to Factor Analyze Your Data Right: Do's, Don'ts, and 
How-To's. International Journal of Psychological Research, 3, 97-110.

Mays, J. M. (2006). Feminist Disability Theory: Domestic Violence against Women with a Disability. Disability and Society, 21, 147-158. https://doi.org/10.1080/09687590500498077

McCloskey, L. (1996). Socioeconomic and Coercive Power within the Family. Gender \& Society, 10, 449-463. https://doi.org/10.1177/089124396010004006

McFarlane, J., Hughes, R. B., Nosek, M. A., Groff, J. Y., Swedland, N., \& Mullen, P. D. (2001). Abuse Assessment Screen-Disability (AAS-D): Measuring Frequency, Type, and Perpetrator of Abuse toward Women with Physical Disabilities. Journal of Women's Health \& Gender-Based Medicine, 10, 861-866. https://doi.org/10.1089/152460901753285750

Nannini, A. (2006). Sexual Assault Patterns among Women with and without Disabilities Seeking Survivor Services. Women's Health Issues, 16, 372-379. https://doi.org/10.1016/j.whi.2006.10.001

Nosek, M. A., Howland, C., \& Hughes, R. B. (2001). The Investigation of Abuse and Women with Disabilities: Going beyond Assumptions. Violence against Women, 7, 477-499. https://doi.org/10.1177/10778010122182569

Nosek, M. A., Young, M. E., Rintala, D., Howland, C. A., Foley, C. C., \& Bennett, J. L. (1995). Barriers to Reproductive Health Maintenance among Women with Physical Disabilities. Journal of Women's Health, 4, 505-518.

Packota, V. J. (2000). Emotional Abuse of Women by Their Intimate Partners: A Literature Review.

http://www.springtideresources.org/resource/emotional-abuse-women-their-intimatepartners-literature-review

Perry, A. R., \& Fromuth, M. E. (2005). Courtship Violence Using Couple Data: Characteristics and Perceptions. Journal of Interpersonal Violence, 20, 1078- 1095. https://doi.org/10.1177/0886260505278106

Porter, J. L., \& McQuiller Williams, L. (2011a). Intimate Violence among Underrepresented Groups on a College Campus. Journal of Interpersonal Violence, 26, 3210-3224. https://doi.org/10.1177/0886260510393011

Porter, J. L., \& McQuiller Williams, L. (2011b). Auditory Status and Experiences of Abuse among College Students. Violence and Victims, 26, 788-798.

https://doi.org/10.1891/0886-6708.26.6.788

Powers, L. E., Renker, P., Robinson-Whelen, S., Oschwald, M., Hughes, R., Swank, P., \& Curry, M. A. (2009). Interpersonal Violence and Women with Disabilities: Analysis of Safety Promoting Behaviors. Violence against Women, 9, 1040-1069. https://doi.org/10.1177/1077801209340309

Rouse, L. P. (1988). Abuse in Dating Relationships: A Comparison of Blacks, Whites, and Hispanics. Journal of College Student Development, 29, 312-319.

Rousso, H. (2001). Strong Proud Sisters: Girls and Young Women with Disabilities (The Barbara Waxman Fiduccia Papers on Women and Girls with Disabilities). Washington DC: Center for Women Policy Studies. http://www.centerwomenpolicy.org/pdfs/DIS3.pdf

Sadusky, J., \& Obinna, J. (2002). Violence against Women: Focus Groups with Culturally Distinct and Underserved Communities. Minneapolis, MN: Rainbow Research.

Saunders, D. (2002). Are Physical Assaults by Wives and Girlfriends a Major Social Problem? A Review of the Literature. Violence against Women, 8, 1424-1448.

https://doi.org/10.1177/107780102237964 
Saunders, D. G. (1998). Wife Abuse, Husband Abuse or Mutual Combat: A Feminist Perspective on the Empirical Findings. In K. Yllo, \& M. Bograd (Eds.), Feminist Perspectives on Wife Assault (pp. 90-113). Thousand Oaks, CA: Sage.

Sebald, A. (2008). Child Abuse and Deafness: An Overview. American Annals of the Deaf, 153, 376-383. https://doi.org/10.1353/aad.0.0059

Schwartz, M. D., \& DeKeseredy, W. S. (1997). Sexual Assault on the College Campus: The Role of Male Peer Support. Thousand Oaks, CA: Sage.

Smith, D. L. (2007). Disability, Gender and Intimate Partner Violence: Relationships from the Behavioral Risk Factor Surveillance System. Sex Disability, 26, 15-28. https://doi.org/10.1007/s11195-007-9064-6

Smith, R., \& Anderson, E. M. (2004). Disability, Gender, and Unemployment Relationships in the United States from the Behavioral Risk Factor Surveillance System. Disability and Society, 19, 403-414. https://doi.org/10.1080/09687590410001689494

Sobsey, D., \& Doe, T. (1991). Patterns of Sexual Abuse and Assault. Sexuality and Disability, 9, 243-259. https://doi.org/10.1007/BF01102395

Spencer, N., Devereux, E., Wallace, A., Sundrum, R., Shenoy, M., Bacchus, C., \& Logan, S. (2005). Disabling Conditions and Registration for Child Abuse and Neglect: A Population-Based Study. Pediatrics, 116, 609-613. https://doi.org/10.1542/peds.2004-1882

SPSS Inc. (2008). SPSS for Windows 17. Chicago, IL: SPSS Inc.

Straus, M. A., Hamby, S. L., Boney-McCoy, S., \& Sugarman, D. B. (1996). The Revised Conflict Tactics Scale (CTS2): Development and Preliminary Psychometric Data. Journal of Family Issues, 17, 283-316. https://doi.org/10.1177/019251396017003001

Sullivan, P. M., \& Knutson, J. F. (2000). Maltreatment and Disabilities: A Population-Based Epidemiological Study. Child Abuse \& Neglect, 24, 1257-1273.

https://doi.org/10.1016/S0145-2134(00)00190-3

Swartz, D. B. (1993). A Comparative Study of Sex Knowledge among Hearing and Deaf College Freshmen. Sexuality and Disability, 11, 129-147.

https://doi.org/10.1007/BF01102192

Turner, H. A., Vanderminden, J., Finkelhor, D., Hamby, S. L., \& Shattuck, A. (2011). Disability and Victimization in a National Sample of Children and Youth. Child Maltreatment, 16, 275-286. https://doi.org/10.1177/1077559511427178

U.S. Department of Justice (1998). Violence by Intimates: Analysis of Data on Crimes by Current or Former Spouses, Boyfriends, and Girlfriends. Washington DC: Bureau of Justice Statistics.

Walker, L. (1979). The Battered Woman. New York, NY: Harper and Row.

World Health Organization (2012). Definition and Typology of Violence. Global Campaign for Violence Prevention, Violence Prevention Alliance.

http://www.who.int/violenceprevention/approach/definition/en/index.html

Yllo, K. (1983). Sexual Equality and Violence against Wives in American States. Journal of Comparative Family Studies, 14, 67-86.

Yllo, K. (1984). The Status of Women, Marital Equality, and Violence against Wives. Journal of Family Issues, 5, 307-320. https://doi.org/10.1177/019251384005003002

Yodanis, C. L. (2004). Gender Inequality, Violence against Women, and Fear: A CrossNational Test of the Feminist Theory of Violence against Women. Journal of Interpersonal Violence, 19, 655-675. https://doi.org/10.1177/0886260504263868

Young, M. E., Nosek, M. A., Howland, C. A., Chanpong, G., \& Rintala, E. H. (1997). Prevalence of Abuse of Women with Physical Disabilities. Archives of Physical Medicine and Rehabilitation, 78, 534-538. 
Submit or recommend next manuscript to SCIRP and we will provide best service for you:

Accepting pre-submission inquiries through Email, Facebook, LinkedIn, Twitter, etc. A wide selection of journals (inclusive of 9 subjects, more than 200 journals)

Providing 24-hour high-quality service

User-friendly online submission system

Fair and swift peer-review system

Efficient typesetting and proofreading procedure

Display of the result of downloads and visits, as well as the number of cited articles Maximum dissemination of your research work

Submit your manuscript at: http://papersubmission.scirp.org/

Or contact psych@scirp.org 